\title{
Determination of the reactivity ratios of methyl acrylate with the vinyl esters vinyl acetate, vinyl 2,2-dimethyl-propanoate, and vinyl 2-ethylhexanoate
}

Citation for published version (APA):

Noel, E. F. J., van Altveer, J. L., Timmermans, M. D. F., \& German, A. L. (1994). Determination of the reactivity ratios of methyl acrylate with the vinyl esters vinyl acetate, vinyl 2,2-dimethyl-propanoate, and vinyl 2ethylhexanoate. Journal of Polymer Science, Part A: Polymer Chemistry, 32(12), 2223-2227.

https://doi.org/10.1002/pola.1994.080321202

DOI:

10.1002/pola.1994.080321202

Document status and date:

Published: 01/01/1994

Document Version:

Publisher's PDF, also known as Version of Record (includes final page, issue and volume numbers)

\section{Please check the document version of this publication:}

- A submitted manuscript is the version of the article upon submission and before peer-review. There can be important differences between the submitted version and the official published version of record. People interested in the research are advised to contact the author for the final version of the publication, or visit the DOI to the publisher's website.

- The final author version and the galley proof are versions of the publication after peer review.

- The final published version features the final layout of the paper including the volume, issue and page numbers.

Link to publication

\footnotetext{
General rights

- You may freely distribute the URL identifying the publication in the public portal. follow below link for the End User Agreement:

www.tue.nl/taverne

\section{Take down policy}

If you believe that this document breaches copyright please contact us at:

openaccess@tue.nl

providing details and we will investigate your claim.
}

Copyright and moral rights for the publications made accessible in the public portal are retained by the authors and/or other copyright owners and it is a condition of accessing publications that users recognise and abide by the legal requirements associated with these rights.

- Users may download and print one copy of any publication from the public portal for the purpose of private study or research.

- You may not further distribute the material or use it for any profit-making activity or commercial gain

If the publication is distributed under the terms of Article $25 \mathrm{fa}$ of the Dutch Copyright Act, indicated by the "Taverne" license above, please 


\title{
Determination of the Reactivity Ratios of Methyl Acrylate with the Vinyl Esters Vinyl Acetate, Vinyl 2,2-Dimethyl-Propanoate, and Vinyl 2-Ethylhexanoate
}

\author{
LILIAN F. J. NOËL, JEROEN L. VAN ALTVEER, MENNO D. F. TIMMERMANS, and ANTON L. GERMAN* \\ Department of Polymer Chemistry and Technology, Eindhoven University of Technology, 5600 MB Eindhoven, \\ The Netherlands
}

\begin{abstract}
SYNOPSIS
The course of composition drift in copolymerization reactions is determined by reactivity ratios of the contributing monomers. Since polymer properties are directly correlated with the resulting chemical composition distribution, reactivity ratios are of paramount importance. Furthermore, obtaining correct reactivity ratios is a prerequisite for good model predictions. For vinyl acetate (VAc), vinyl 2,2-dimethyl-propanoate also known as vinyl pivalate (VPV), and vinyl 2-ethylhexanoate (V2EH), the reactivity ratios with methyl acrylate (MA) have been determined by means of low conversion bulk polymerization. The mol fraction of MA in the resulting copolymer was determined by ${ }^{1} \mathrm{H}$-NMR. Nonlinear optimization on the thus-obtained monomer feed-copolymer composition data resulted in the following sets of reactivity ratios: $r_{\mathrm{MA}}=6.9 \pm 1.4$ and $r_{\mathrm{VAc}}=0.013 \pm 0.02 ; r_{\mathrm{MA}}=5.5$ \pm 1.2 and $r_{\mathrm{VPV}}=0.017 \pm 0.035 ; r_{\mathrm{MA}}=6.9 \pm 2.7$ and $r_{\mathrm{V} 2 \mathrm{EH}}=0.093 \pm 0.23$. As a result of the similar and overlapping reactivity data of the three methyl acrylate-vinyl ester monomer systems, for practical purposes these data can be described with one set of reactivity data. Nonlinear optimization of all monomer feed-copolymer composition data together resulted in $r_{\mathrm{MA}}=6.1 \pm 0.6$ and $r_{\mathrm{VEst}}=0.0087 \pm 0.023$. (C) 1994 John Wiley \& Sons, Inc.
\end{abstract}

Keywords: bulk $\bullet$ copolymerization $\bullet$ reactivity ratios $\bullet$ methyl acrylate $\bullet$ vinyl esters

\section{INTRODUCTION}

Vinyl acetate copolymers are widely used in interior architectural coatings. Due to the poor hydrolytic stability of these copolymers, their use as exterior coatings is limited. Vinyl ester monomers of the C9C11 versatic acids, as produced by Shell, have been available in Europe for about 25 years. ${ }^{1,2,3}$ As a result of recently developed large scale transvinylation methods, new vinyl ester monomers have been produced by the Union Carbide Corporation. ${ }^{4}$ Due to neighboring group steric effects, the use of these monomers in emulsion copolymerization results in improved hydrolytic stability and water resistance when compared with vinyl acetate. ${ }^{1,2,3}$ Furthermore, glass transition temperatures of ( $\mathrm{co}$ ) polymers will

\footnotetext{
* To whom all correspondence should be addressed.
}

Journal of Polymer Science: Part A: Polymer Chemistry, Vol. 32, 2223-2227 (1994) (c) 1994 John Wiley \& Sons, Inc. strongly depend on the vinyl ester used. In this way copolymers can be designed over a wide range of glass transition temperatures.

Next to resistance against hydrolysis and glass transition temperatures, the product properties are also determined by the heterogeneity of the copolymer. Predictions of composition drift are, therefore, very important. With the reactivity ratios at hand, predictions of the chemical composition distribution can be performed for copolymerization reactions in both homogeneous (bulk and solution) and heterogeneous (emulsion) systems. Although only small differences in reactivity ratios have been observed in vinyl acetate-vinyl esters copolymerization reactions $\left(r_{\mathrm{VAc}} \approx r_{\mathrm{VEst}}\right)$, composition drift occurring in copolymerization reactions of, for instance, an acrylic monomer with vinyl acetate may be affected by replacing vinyl acetate by another vinyl ester. Since acrylic polymers are often used in various applications, it is important to know whether 
or not the reactivity ratio of MA with vinyl esters can be approximated by the reactivity ratio of vinyl acetate, often already known. For this reason the reactivity ratios of methyl acrylate-vinyl esters have been determined for vinyl acetate (VAc), vinyl 2,2dimethyl-propanaoate (VPV), and vinyl 2-ethylhexanoate (V2EH). These monomers have been selected since they do not consist of isomeric mixtures.

The general structure of the MA-VEst copolymers is given by:

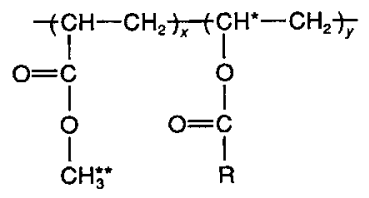

In this structural formula the left hand group $(x)$ represents the MA units and the right hand group $(y)$ represents the vinyl ester units in the copolymer. The R-group in the structural formula stands for a $\mathrm{CH}_{3}, \mathrm{C}_{4} \mathrm{H}_{9}$, and $\mathrm{C}_{7} \mathrm{H}_{15}$ group representing the monomers VAc, VPV, and V2EH, respectively.

For MA-VAc copolymerizations the reactivity ratios have been determined before by several investigators using different copolymer analysis methods, as polymer hydrolysis followed by acetic acid determinations, ${ }^{5}$ infrared spectroscopy,${ }^{6}$ interferometry, ${ }^{7}$ and ${ }^{1} \mathrm{H}$-NMR. ${ }^{8}$ However, the monomer feed-copolymer composition data thus obtained sometimes lack accuracy. ${ }^{5}$ Furthermore, the reactivity ratios have been calculated by traditional linearization techniques ${ }^{9,10,11}$ of the instantaneous copolymer equation ${ }^{12,13}$ given by:

$$
F_{i}=\frac{r_{i} f_{i}^{2}+f_{i} f_{j}}{r_{i} f_{i}^{2}+2 f_{i} f_{j}+r_{j} f_{j}^{2}}
$$

where $F_{i}$ stands for the copolymer composition in mol fraction of monomer, $i f_{i}$, and $f_{j}$ are the mole fractions of monomers $i$ and $j$ in the feed, and $r_{i}$ and $r_{j}$ are the reactivity ratios of monomers $i$ and $j$ in the selected monomer combination $i-j$. Recently, more accurate nonlinear optimization techniques have been developed to determine reactivity ratios. ${ }^{14,15}$ In this article the reactivity ratios are determined by the nonlinear optimization technique described by Dubé et al. ${ }^{15}$ taking into account the estimated experimental error in both monomer feed and copolymer composition.

A typical $400 \mathrm{MHz}{ }^{1} \mathrm{H}-\mathrm{NMR}$ spectrum of a low conversion bulk MA-V2EH copolymer is given in Figure 1. The total peak area represented by $A$ in Figure 1 is generated as a result of the resonance of

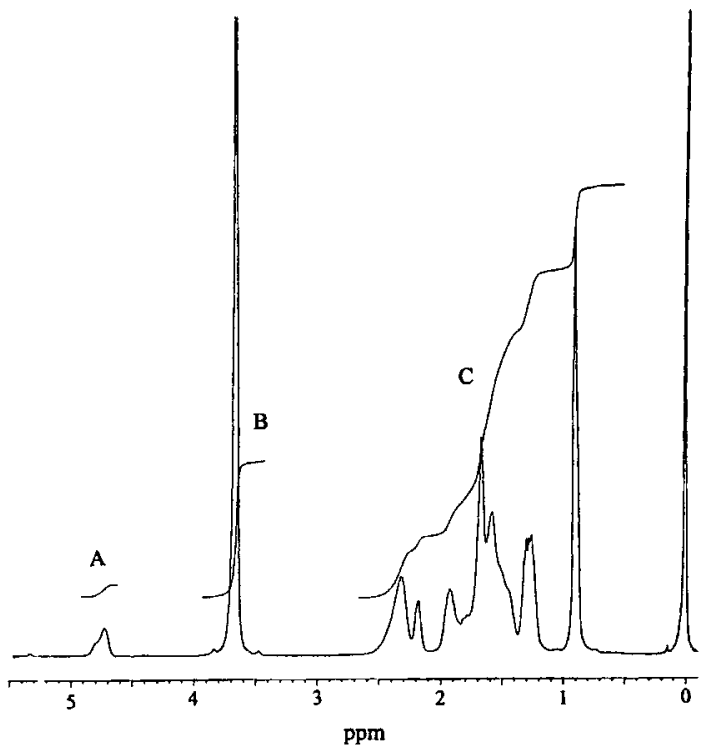

Figure 1. A typical ${ }^{1} \mathrm{H}-\mathrm{NMR}$ spectrum of a MA-VEst copolymer. The total peak areas represented by $A, B$, and $\mathrm{C}$ result from 1 VEst proton, $3 \mathrm{MA}$ protons, and all other protons, respectively.

the V2EH proton marked by '*' in the above given structural formula of the copolymer. The peak area $B$ is generated by the three methyl group protons of MA in the copolymer. This methyl group is indicated by '**' in the structural formula. The peak area generated by all other protons is represented by $\mathrm{C}$ in Figure 1. Note that the number of protons in the side group (and, therefore, the total peak area of $\mathrm{C}$ as compared with A and B) will change with each selected vinyl ester. Calculation of the average copolymer composition of all MA-VEst copolymers ( $m o l$ fraction MA: $F_{\text {MA }}$ ) can be determined from the peak areas $A$ and $B$ in the ${ }^{1} \mathrm{H}-\mathrm{NMR}$ spectra by using the following relationship:

$$
F_{\mathrm{MA}}=\frac{\mathrm{B}}{3 \mathrm{~A}+\mathrm{B}}
$$

\section{EXPERIMENTAL}

\section{Materials}

The following materials were used for the low conversion bulk copolymerization reactions: reagent grade methyl acrylate (MA, Janssen Chimica), vinyl acetate (VAc, Janssen Chemica), vinyl 2,2-dimethyl-propanoate (VPV, product names VEOVA5 from Shell and Vynate NEO-5 from Union Carbide Corporation), and vinyl 2-ethylhexanoate (V2EH, 
product name vynate $2 \mathrm{EH}$, Union Carbide Corporation) as monomers, and 2,2'-azobis (2-methylpropionitrile) (AIBN, Janssen Chimica, Tilburg, The Netherlands) as initiator. Before use, the monomers were distilled under reduced pressure in order to remove inhibitor. The middle fraction was cut and stored at $4^{\circ} \mathrm{C}$.

\section{Determination of the Reactivity Ratios from Bulk Polymerizations}

Bulk copolymerizations were carried out in $20-\mathrm{mL}$ bottles thermostated at $50^{\circ} \mathrm{C}$ and mixed with a magnetic stirrer. The reaction mixture consisted of $20 \mathrm{~g}$ of monomer with different monomer mol fractions ranging from $10-90 \mathrm{~mol} \% \mathrm{MA}$ and $0.1 \mathrm{~g}$ AIBN as initiator. The reactions were stopped at low conversion $(<3 \%)$ in order to prevent composition drift, by pouring the total reaction mixture in heptane. To determine the copolymer composition of the resulting copolymer, a $400 \mathrm{MHz}{ }^{1} \mathrm{H}-\mathrm{NMR}$ spectrum (Bruker AM 400) was taken at $298 \mathrm{~K}$ using $\mathrm{CDCl}_{3}$ as solvent and locking agent. From the relative peak areas in this spectrum the copolymer composition could be determined. The resulting monomer feed fraction-copolymer composition data are shown in Table I.

\section{RESULTS AND DISCUSSION}

\section{Reactivity Ratios}

Predictions of the course of copolymerization reactions as a function of conversion can be performed only in those cases where the reactivity ratios are known accurately. For the monomer combination
MA-VAc the reactivity ratios have been determined before by Kulkarni et al. ${ }^{8}$ resulting in the following reactivity ratios: $r_{\mathrm{MA}}=6.3 \pm 0.4$ and $r_{\mathrm{VAc}}=0.031$ \pm 0.006 . However, these reactivity ratios have been determined by linearization of the instantaneous copolymer equation. Recently, better nonlinear optimization techniques have been developed, ${ }^{14,15}$ making more realistic determinations of the reactivity ratios possible by taking into account experimental errors in the monomer feed and copolymer composition. The results of newly obtained monomer feed-copolymer composition data for MA-VAc are given in Table I.

For the monomer combinations MA-VPV and MA-V2EH no reactivity ratios were found in the literature. In order to see whether or not the reactivity ratios for the investigated MA-VEst systems are similar, low conversion bulk polymerizations have to be performed in order to actually determine the reactivity ratios. These reactivity values were determined by nonlinear optimization ${ }^{15}$ of the monomer feed-copolymer composition data summarized in Table I. When calculating reactivity ratios with this nonlinear optimization method, errors in both the monomer feed composition (estimated to be $0.1 \%$ ) and the copolymer composition (estimated to be $3 \%$ ) are taken into account.

The reactivity ratios resulting from nonlinear optimization of the monomer feed-copolymer composition data (Table I) are given in Figure 2, together with the $95 \%$ reliability intervals and in Table II. It should be mentioned that the large reliability interval on the reactivity ratio of $\mathrm{V} 2 \mathrm{EH}$ in the MA$\mathrm{V} 2 \mathrm{EH}$ monomer combination is a result of the lack of monomer feed-copolymer composition data at low MA feed ratios. Bulk polymerizations of MA-V2EH, performed at low MA feed ratios, were extremely

Table I. Monomer Feed $\left(f_{\text {MA }}\right)^{\mathrm{a}}$

\begin{tabular}{cccccc}
\hline $\begin{array}{c}f_{\text {MA }} \\
\text { MA-VAc }\end{array}$ & $\begin{array}{c}F_{\text {MA }} \\
\text { MA-VAc }\end{array}$ & $\begin{array}{c}f_{\text {MA }} \\
\text { MA-VPV }\end{array}$ & $\begin{array}{c}F_{\text {MA }} \\
\text { MA-VPV }\end{array}$ & $\begin{array}{c}f_{\text {MA }} \\
\text { MA-V2EH }\end{array}$ & $\begin{array}{c}F_{\text {MA }} \\
\text { MA-V2EH }\end{array}$ \\
\hline 0.100 & 0.616 & 0.144 & 0.637 & 0.329 & 0.784 \\
0.181 & 0.704 & 0.275 & 0.742 & 0.400 & 0.832 \\
0.200 & 0.71 & 0.393 & 0.826 & 0.462 & 0.873 \\
0.300 & 0.803 & 0.597 & 0.889 & 0.600 & 0.916 \\
0.600 & 0.935 & 0.691 & 0.926 & 0.658 & 0.935 \\
0.700 & 0.924 & 0.779 & 0.966 & 0.670 & 0.930 \\
0.800 & 0.979 & & & 0.700 & 0.959 \\
& & & & 0.800 & 0.984 \\
\hline
\end{tabular}

\footnotetext{
a Copolymer composition ( $\left.F_{\mathrm{MA}}\right)$ data (both in monomer mol fractions) of the monomer system MA-VAc, MA-VPV, and MA-V2EH obtained by ${ }^{1} \mathrm{H}-\mathrm{NMR}$ of low conversion bulk polymerizations products.
} 


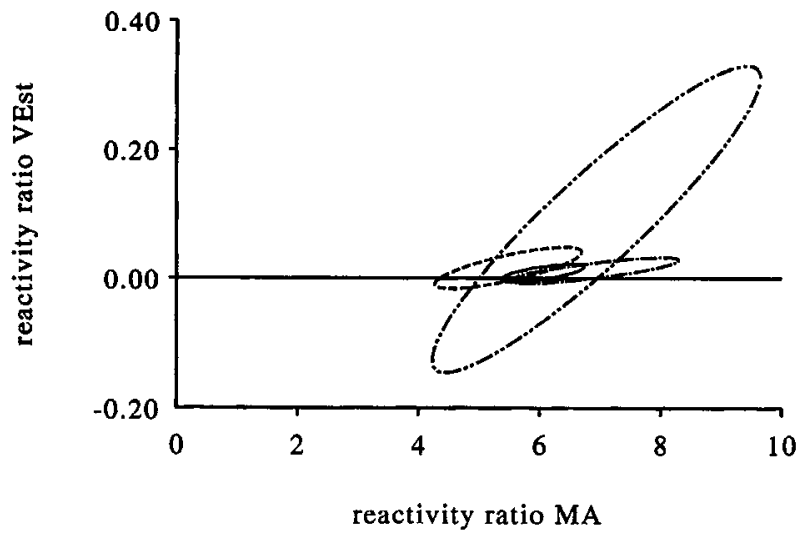

Figure 2. The 95\% reliability intervals are given for the reactivity ratios of MA-VAc (---), MA-VPV (-- ), MA-V2EH (- - - ), and the total MA-VEst reactivity ratios $(-)$.

sensitive to inhibition. For this reason no reactions at low MA feed ratios could be performed. From the results in Table II and Figure 2 it can be concluded that no significant differences are found between the reactivity ratios of the three monomer systems. Therefore, for practical purposes they can be estimated with one set of reactivity ratios. This pair of overall reactivity ratios was obtained by nonlinear optimization of all monomer feed-copolymer composition data of the three MA-VEst systems together. Due to the increased number of data points, the $95 \%$ reliability interval and the error bars on the reactivity ratios have decreased resulting in the following reactivity ratios:

$$
r_{\mathrm{MA}}=6.06 \pm 0.6 \text { and } r_{\mathrm{VEst}}=0.0087 \pm 0.023
$$

This result is in acceptable agreement with the reactivity ratios determined by Kulkarni et al. ${ }^{8}$ for MA-VAc $\left(r_{\mathrm{MA}}=6.3 \pm 0.4\right.$ and $\left.r_{\mathrm{VAc}}=0.031 \pm 0.006\right)$.

When using the overall set of reactivity ratios,

Table II. Reactivity Ratios of MA-VEst Monomer Combinations as Determined from Low Conversion Bulk Polymerizations at $50^{\circ} \mathrm{C}$

\begin{tabular}{lcl}
\hline \multicolumn{1}{c}{ Vinyl Ester } & MA & \multicolumn{1}{c}{ VEst } \\
\hline Vinyl acetate & $6.90 \pm 1.4$ & $0.013 \pm 0.02$ \\
$\begin{array}{l}\text { Vinyl 2,2-dimethyl- } \\
\quad \text { propanoate }\end{array}$ & $5.5 \pm 1.2$ & $0.017 \pm 0.035$ \\
$\begin{array}{l}\text { Vinyl 2-ethylhexanoate } \\
\text { Overall vinyl esters }\end{array}$ & $6.9 \pm 2.7$ & $0.093 \pm 0.23$ \\
\hline
\end{tabular}

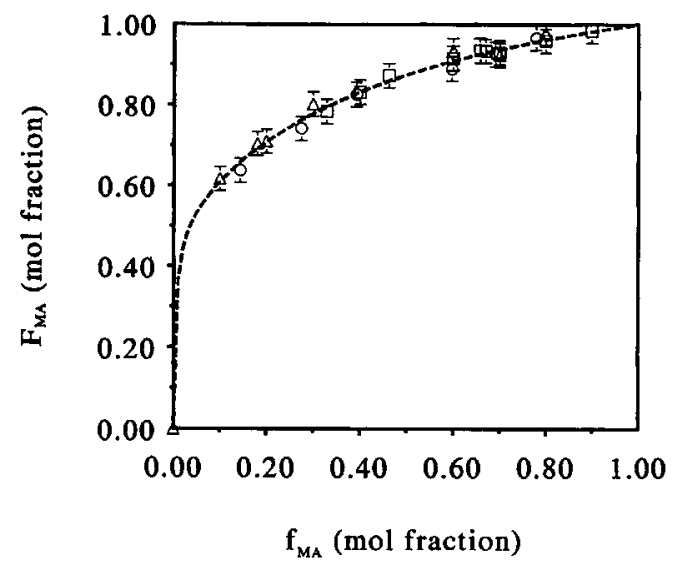

Figure 3. Comparison of the experimentally determined monomer feed-copolymer composition data of MA with VAc $(\triangle)$, VPV $(O)$, and V2EH $(\square)$ monomer systems with the theoretical instantaneous copolymer equation $(---)$ using the reactivity ratios $r_{\mathrm{MA}}=6.1$ and $r_{\mathrm{VEst}}$ $=0.0087$.

the monomer feed-copolymer composition relationship can be described theoretically using the instantaneous copolymer equation [Eq. (1)]. Comparing experimental results with the theoretical prediction of the instantaneous copolymer equation using the reactivity ratios $r_{\mathrm{MA}}=6.06$ and $r_{\mathrm{VEst}}=0.0087$ gives good agreement, as can be seen in Figure 3. From these results it can be concluded that all three monomer combinations indeed can be described with one set of reactivity ratios.

An advantage of the approximately equal reactivity ratios for VAc, VPV, and V2EH in MA-VEst monomer systems is that these systems can be used as a tool in studying the important effect of the monomer solubility in water on the course of emulsion copolymerization reactions of MA-VEst, as a function of the monomer to water ratio. We will report on these aspects in a separate article.

\section{CONCLUSIONS}

Reactivity ratios of methyl acrylate with the vinyl esters vinyl acetate, vinyl 2,2-dimethyl-propanoate, and vinyl 2-ethylhexanoate have been determined by a nonlinear optimization technique applied to the monomer feed-copolymer composition data obtained from low conversion bulk polymerization reactions. This resulted in the following reactivity ratios: 


$$
\begin{aligned}
\text { MA-VAc: } r_{\mathrm{MA}} & =6.9 \pm 1.4 \text { and } \\
r_{\mathrm{VAc}} & =0.013 \pm 0.03 \\
\text { MA-VPV: } r_{\mathrm{MA}} & =5.5 \pm 1.2 \text { and } \\
r_{\mathrm{VAc}} & =0.017 \pm 0.035 \\
\text { MA-V2EH: } r_{\mathrm{MA}}= & 6.9 \pm 2.7 \text { and } \\
r_{\mathrm{VAc}} & =0.093 \pm 0.23
\end{aligned}
$$

On the basis of the above shown overlapping reactivity ratios it was concluded that the reactivity of the three MA-VEst monomer systems can be described with one set of reactivity ratios. Nonlinear optimization of all monomer feed-copolymer composition data of the MA-VEst systems resulted in the following overall reactivity data: $r_{\mathrm{MA}}=6.1 \pm 0.6$ and $r_{\mathrm{VEst}}=0.0087 \pm 0.023\left(50^{\circ} \mathrm{C}\right)$.

L. F. J. Noël is indebted to SON (Stichting Scheikundig Onderzoek in Nederland) for financially supporting this work. We thank Denis Heymans from Shell Research S. A. in Louvain-la-Neuve, Belgium, and David R. Bassett and Martha J. Collins from the Union Carbide Corporation in South Charleston, United States for supplying us with samples of the vinyl ester monomers.

\section{REFERENCES}

1. H. P. H. Scholten, J. Vermeulen, A New Versatile Building Block for High-Performance Polymeric Binders, XIX Fatipec Conference, Aachen, 18-24, 1988.

2. W. C. Aten, Effect of Composition and Molecular Weight on the Performance of Latices Based on Vinyl
Ester of Versatile Acid in Modern Emulsion Paints, XVIIth Fatipec Congress, Lugano, 1984.

3. M. M. C. P. Slinckx, H. P. H. Scholten, Veova 9/ (Meth) Acrylates, A New Class of Emulsion Copolymers, 19th Water-Borne, Higher Solids and Powder Coating Symposium, New Orleans, La., 1992.

4. R. E. Murray, U.S. Pat. 4,981,973 (1991) (to Union Carbide).

5. F. R. Mayo, C. Walling, F. M. Lewis, and W. F. Hulse, J. Am. Chem. Soc., 70, 1523 (1958).

6. T. A. Garrett and G. S. Park, J. Polym. Sci., 4, A-1, 2714 (1966).

7. I. S. Avetisyan, V. I. Eliseeva, and O. G. Laronovo, Vysokomol. Soedin, 3, A 9, 570 (1967).

8. N. G. Kulkarni, N. Krishnamurti, P. C. Chatterjee, and M. A. Sivasamban, Makromol. Chem., 139, 165 (1970).

9. F. R. Mayo and F. M. Lewis, J. Am. Chem. Soc., 66, 1594 (1944).

10. M. Fineman and S. D. Ross, J. Polym. Sci., 5, 259 (1950).

11. T. Kelen and F. Tüdös, J. Macromol. Sci., Chem., A9, 1 (1975).

12. T. Alfrey and G. Goldfinger, J. Chem. Phys., 12, 205 (1944).

13. F. R. Mayo and F. M. Lewis, J. Am. Chem. Soc., 66, 1594 (1944).

14. F. L. M. Hautus, H. N. Linssen, and A. L. German, J. Polym. Sci., Polym. Chem. Ed., 22, 3487, 3661 (1984).

15. M. Dubé, R. Amin Sanayei, A. Penlidis, K. F. O'Driscoll, and P. M. Reilly, J. Polym. Sci., Polym. Chem., 29, 703 (1991).

Received November 10, 1993

Accepted February 22, 1994 